\title{
IMPLEMENTATION OF ENTERPRISE SYSTEMS AS A STRATEGIC MOVE FOR STRENGTHENING A COMPANY'S COMPETITIVE ADVANTAGE
}

\author{
Andrzej KAMIŃSKI \\ Faculty of Management, Warsaw University of Technology, Warsaw, Poland \\ e-mail: a.kaminski@wz.pw.edu.pl
}

\begin{abstract}
This article discusses how the restructuring linked with broadly defined informatisation program can be used to gain a strategic competitive advantage in business. This problem is illustrated with an example representing the introduction of information technologies in the Municipal Transport Company (Miejskie Przedsiębiorstwo Komunikacyjne), as well as analysis and evaluation of the implementation of human resource management system. The analysis was carried out in the operational and strategic areas.
\end{abstract}

Keywords: reducing costs, improving work organisation, storage resources control, applicant tracking systems, comprehensive computerisation, implementation of management information system.

\section{Introduction}

The main objective of economic modern enterprise in a market economy - is primarily to maximise company is obliged to effectively utilise the available fixed assets, financial resources and employees' potential or analyse the environment in which it operates.

Continuous micro- and macroeconomic analysis makes the company in the development process sustain growth, adapting functions, objectives and tasks, and organisation and management methods to changing business conditions. Competitive business should have internal ability and flexibility to adapt to changing operating conditions and obtain the specific benefits of this process.

The modern concept of creating a competitive advantage puts special emphasis on the need for skilful use of acquired knowledge and resources, and effective use of information technology (IT) in management decision-making processes [5]. IT supports the managerial decision-making process based on the various data sets, analysis, opinions, or advisory studies and reports.

Enterprise system strategy is the hierarchically highest structured component of management system and is characterised by high task-information dynamics [12]. An inherent element of the IT strategy is the integration of hardware infrastructure and telecommunications systems supporting management processes and operating and database environments.

Enterprise systems integration is possible through the implementation of complex and multifunctional packages of Enterprise Resource Planning (ERP). ERP sys- tem is a suite of integrated, highly efficient and multiuser applications built for the comprehensive management of manufacturing industrial company.

ERP system, subject to continuous improvement and evolution, has become the most widely used tool for production planning and control in large and medium-sized enterprises (business activities of $70 \%$ computerised industrial enterprises in the developed countries of Western Europe are based on computer systems compliant with ERP).

ERP system covers core business processes of production and distribution that integrates various company departments, facilitates information flow between all business functions and ensures quick response to the changes in demand. This information is updated in realtime and available at the time of making decision (for systems operating online).

Enterprise systems implementation will not only eliminate data reduction and reduce a significant number of errors (resulting from repeated entries of the same data into the system by different people) but also allows implementing different configuration processes developed on the basis of a full analysis of the system.

Introduction of enterprise systems supporting the company management results in measurable economic benefits that include:

- reducing costs by eliminating data redundancy, reducing operational activities through the implementation of process management model, as well as the automation procedures for monitoring and control of material resources, 
- improving work organisation and the use of new methods of quality control up to the normative standards of ISO 9000 and ISO 14000, which is dictated by the applied implementation methodology and logic of the system,

- integration of procedures and functions, standardisation of source documents formsand the development of document management procedures (document flow project, control access rights, archive policy),

- access capability to real-time information about current economic events, current analysis of selected economic indicators (i.e., liquidity, profitability, inventory levels, settlements),

- control of accounts receivable and liabilities, the implementation of mechanisms for recipient monitoring and suspension of the execution of orders in case of arrears in payment (the ability to define for each client the loan amount and payment period),

- storage resources control, the possibility of transfer of materials between warehouses, automated monitoring of inventory and raw materials, notification of the need to supplement them,

- implementation of management information system, the ability to conduct multi-criteria analysis of operational and financial data (see $[4,8.10]$ ); implementation of enterprise systems must be closely linked and correlated with the methodology of restructuring changes implementation.

In the implementation of MRP/ERP systems, the assessment of the degree of compromise between the package functionality and its susceptibility to modifications and changes and the need for the restructuring in the company are very important.

At present, the technology of modern enterprise systems allows them to be adapted to the specific nature and needs of a particular company. However, the costs of implementing, testing, documentation and maintenance of these changes have a significant impact on the budget of the project.

Any changes in standard software architecture also increase the risk of the whole project.

\section{The concept of the methodical implementa- tion of the information system project sup- porting the staff management at the Municipal Transport Company (MTC)}

\subsection{Definition of the project, purpose and scope of implementation}

Changes in the passenger transport market, in particular, demonopolisation of the market and introduction of competition rules in the selection of particular lines operators, have forced introduction of restructuring changes in national communication companies. The strategic objective of the broader restructuring is to improve the quality of services, cost reduction and reorganisation of management processes. In the implementation of restructuring and change projects, fully effective use of computer technology (implementation of enterprise systems MRP/ERP), communication techniques (digital telephony, Internet, Intranet) and modern tools and applications that automate office work, engineering, manufacturing, services and administrative work play an important role. The use of IT in restructuring business processes companies does not, however, mean the automation and computerisation of existing processes, but the search for and development of new patterns, models and solutions. IT offers a wide spectrum of projects supporting restructuring, beginning with the implementation of standard software packages, and ending with the construction of systems dedicated to the needs of a business organisation.

On the basis of the above considerations, it is possible to formulate a working thesis that the implementation of enterprise systems MRP/ERP provides an efficient support for restructuring changes in the company and brings benefits in the functional and strategic areas.

In detail:

- outcome of the functional area: employees benefit from the automation of processes, e.g. one-shot input of source documents into the system and the possibility of obtaining rights of access to functions associated with a particular task;

- benefits of the strategic area: management has the ability to assess the current financial condition of the company monitoring the level of material resources and storage, rational planning of activities in the area of staff management, wage policies, improvement and development of human resources (HR), and intervention in case of irregularities. 
The introduction of the implementation of supporting staff management project in the Municipal Transport Company (Miejskie Przedsiębiorstwo Komunikacyjne; MPK) and the analysis of technical-organisationaleconomic effects resulting from the IT project accomplishment are presented in the following sections of this work. On the basis of empirical studies, a close relationship between the completion of the various stages of project implementation and the restructuring of $\mathrm{HR}$ processes is demonstrated.

\subsection{Organisation of the project}

The development of information systems for personal processes is closely linked to the development of methods and techniques of HR management. In the 1990s, the functionality of personnel-payroll systems recorded the basic personal data of employees and payroll. Currently, this class of systems has been enhanced with modern features in the so-called strategic HR management supporting: modelling of the organisational structure, workforce planning, recruitment, management training and capacity building, as well as the assessment of labour and bonus schemes. It is worth noting that a change in approach to the management of HR in the business organisation was driven by several factors, namely, increase in labour costs in the enterprise, the impact of the HR function in the development of productivity and thus the impact on the competitiveness of the company and its market position, increase of employees creativity, and increase of the role of organisational culture in modern enterprises [6].

The use of IT in the computer-aided management of human capital is related to the increasing pressure to increase the efficiency, speed and cost reduction of the implementation of specific HR functions [2]. Computerisation may include some or all personnel functions. In particular, it may be applied to increase efficiency in the selected area or a wider one, building competitive advantage across the enterprise. For example, the recruitment and selection process increasingly involves the use of specialised applications and information systems category Applicant Tracking Systems (ATS).

The functionality of the ATS system includes publishing and export advertisements for print and online media; recruitment channel management and collection of information about the sources of origin of the candidates; advanced sorting and search listings, applications, and candidates; and even examination of the alignment degree of candidates to the designated criteria. The popularity of the recruitment process management systems in Poland is prevalent among big companies (over 250 employees), where every third employer uses this class of applications [11]. Applications of ATS can be an integral module of larger systems installed in the company covering many areas of its business that are often implemented by large companies.

On the other hand, smaller companies have the opportunities to take advantage of the solutions available in the Software as a Service model on a lease, usually at constant subscription payments. It is more advantageous financially and the responsibility for the maintenance and safety remains with the supplier.

Therefore, more and more enterprises introduce complex and multi-process supporting personnel management systems in place of simple applications supporting the records of employees and payroll. The popularity of these category solutions is also associated with the development of the domestic producers of integrated packages MRP/ERP, firms providing consulting, implementation and information services as well as Poland's integration with the European Union (EU) countries.

The domestic market for computer systems supporting staff management should be assessed both as mature and competitive. For the specific needs of the Polish market and national legislation, solutions offered by reputable manufacturers including software companies SAP, Oracle, or IFS were adopted. Systems supporting personal processes are also offered by domestic companies of the IT industry, which effectively compete with Western solutions. The leading domestic providers of systems integrators include TETA, COMARCH and SOFT-LAB.

Recommended for Municipal Transport Company (MTC) information system should certainly support the management processes at the functional and strategic levels. It should be noted that the implementation of advanced features includes: employees relationship management, forecasting and simulations of wage costs, job evaluation techniques, as well as linking staff development policy with the company's strategy that 


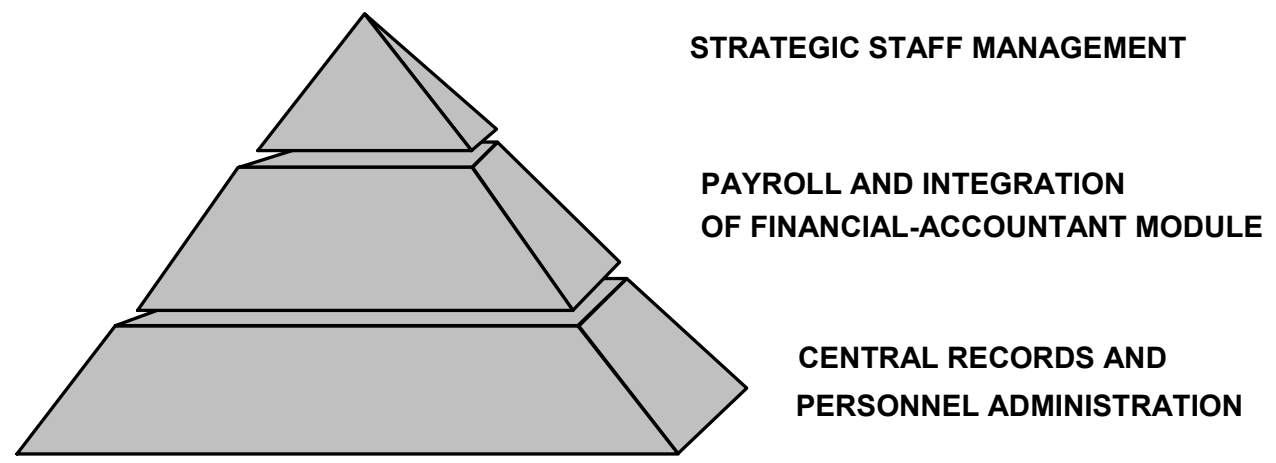

Figure 1. The implementation of system supporting human resources management: stages of work implementation (source: own elaboration)

requires a reorganisation of primary and secondary processes associated with HR and payroll records.

The project of implementation of the systems supporting HR (Fig. 1) in the Municipal Transport Company (MPO) is initiated by a functional analysis proceeding to three implementation stages:

Stage 0 - Functional analysis

Stage 1 - Implementation of the software functionality in the central records and personnel administration area

Stage 2 - Implementation of the software functionality in the payroll area including the integration of financial-accountant module

Step 3 - Implementation of the software functionality in the area of strategic HR management. The material effects of the realisation of specific implementation tasks and economic effects associated with the launch of the supporting system of staff management functionality will be discussed in detail in the following sections of this article.

\subsection{Functional analysis}

The purpose of functional analysis is a new circuit design of source documents, the specification of inputs and outputs, and a coherent approach to the restructuring of business processes (reorganisation of functions, processes and organisational structures) for the project system.

The primary carrier in the process of personal information is source documents. They form the basis of personnel records and from the legal standpoint are important players. The classification of personnel documents can be carried out according to various criteria.
Due to the place of issue, the personnel documents can be divided as follows [7]:

- Internal - made by different entities of the organisation; examples are contract of employment, job description, roles and responsibilities, recognition of improved qualifications, documents related to the granted prizes and awards, and application for leave,

- External - made by various entities of the company's environment; examples are previous employment certificates, skills for work certificate, periodic health examination, statutes and regulations.

According to the type of recipient, personnel documents can be divided as follows [7]:

- Internal - produced for different stakeholders of the organisation, i.e. structure of employment report, labour costs reports, work time and holiday settlement reports, and employee development certification,

- External - produced for various entities of the organisation's environment, i.e. Social Security documents, a report on the state of employment for the Central Statistical Office, and employment and earnings certificate for banks and other institutions.

The introduction of the implementation of supporting staff management project in the Municipal Transport Company (MTC) embraced a framework for the analysis of factual records and verification of all types of documents currently operating in the area of payroll, development of a new business process configuration, verification of wage components and algorithms for each professional MTC group, and the implementation of employee development and training concept. 
More specifically, functional analysis included the following categories of work:

- registration and substantive verification of all types of documents existing in the area of payroll including:

- analysis of the structure of source documents recorded in currently working MTC information systems (e.g. payroll software) and helper applications (e.g. MS Excel spreadsheet package used for storing personal data of employees),

- analysis of the records and reports structure issued by the currently operated systems in the MTC, automated reports (e.g. through manual data consolidation in MS Excel spreadsheet) and hand written reports,

- evolving document classification rules (e.g. classification into official documents and internal MTC documents) and assigning each document to separate earlier category:

o development of a record of divergences the list of redundant and missing documents/reports,

0 the structure and information content development of new documents/reports,

- development of a new configuration of business processes in the area of payroll including:

- analysis of document flow system in the area of HR: payroll and analysis of information linkages with other organisational units of the company,

- assessment of data redundancy, i.e. repeatedly entering the same data and information into various domain database systems,

- project of the business processes new organisation in the area of payroll for the enforcement of computing system project,

- verification of components and algorithms wage for each MPK professional group including:

- registration of salary components together with a description of the legal grounds or reference to the MTC internal regulations,

- developing payroll algorithms for individual MPK company occupational groups,

- development of the implementation concept of staff training and development in the MPK system including:

- development of the organisation planning principles: evidence principles of the organisational structure and the structure and job descriptions (competency requirements, rights and obligations),

- development of staff recruitment rules: the rules of applications for the recruitment needs (unification and joint planning for the similar needs of different branches/depots), the criteria for staff recruitment (individual candidate competency profile) and the principles of candidate assessment,

- development of employment eligibility and selection rules for each job: the principles of detailed description of the employee competence in relation to particular occupational groups in the MPK and the rules of periodic employee appraisals,

- career path development planning: the principles of the development and upgrading workers' skills and the rules of defining career paths for individual employees (by succession according defined key positions and career levels).

According to the normative standards for project implementation, a report of the analytical works has been submitted for approval to the Steering Committee that acted as the so-called Project Supervisory Board. Upon acceptance of this document, proper implementation works related to configuration, parameterisation and training for future users have been carried out. On the other hand, after the completion of the implementation, the individual modules of the system have been put in operation.

\subsection{Implementation of the functionality in the central records and personnel administration}

The first stage of implementation is launching a centralised system of personnel records (personal data, competences and rights of the employee, permanent payroll information) and personnel records system (recruitment, dismissal, records of absence, sick leave, holidays, etc.). The material effect of the first stage is produced by homogeneous information system (based on a central database) supporting HR management at the operational level (access to current information on the employee and his archival data) and at the strategic level (automated generation of reports and statistics on selected occupational groups). Access to the various categories of personal data has been carried out in accordance with a scheme of roles and permissions. Obligatorily, the new system meets the requirements of the Data Protection Act. Bearing in mind a barely 
existent central personal database and personnel records system at the Municipal Transport Company $(M P O)$, tangible benefits at both the operational and strategic levels have been achieved.

- Operational level

Organisation and centralisation of information resources, eliminating data redundancy, i.e. repeatedly entering the same data into domain systems, the ability to access employee data from any corporate terminal network saving the log-in and access authorisation procedures. Registration of employee personal data and other required information (qualifications, periodic health examination, training and courses, etc.).

Implementing standard operating procedures and information systems to ensure that processing and archiving of personnel data are secure. Hitherto, dispersion, disintegration and outdated technology of the existing Municipal Transport Company $(M P O)$ applications that stored personal data did not guarantee the minimum security paradigms. For example, the use of MS Office software to build personal records does not allow the implementation of the basic mechanisms of authorisation and access control to information. What is more, the lack of elementary file security creates a real opportunity for stealing personnel data or execution of illegal copies. Another example is the manual transfer of payroll drivers' data to the "Payer" program. This transfer involves manually copying the payroll drivers' data for the current accounting period. These data are copied from the local servers of branch offices (Municipal Transport Company depots) and then manually merged and loaded into the "Payer". This process does not meet the minimum security requirements and also generates high costs associated with control of the accuracy of data transfer (two employees were assigned to it). It is obvious that the introduction of an information central system will eliminate the identified anomaly, ensure security of personal data and significantly reduce processing costs.

\section{- Strategic level}

Acquisition: timely and accurate reports on personal resources. Up to now, the preparation of a simple report on the structure of staff employment in the Municipal Transport Company (MPO) referring to seniority and rates broken down by occupational groups required manually copying, merging and formatting data of a number of distributed applications. These applications stored only fragmentary portions of the data. Due to the variety of data formats, the lack of a standardised identification of employees and dispersion of information, the process was time-consuming (on the average, two or three person-days). The quality and reliability of the hand written statements and reports (manually copying and merging of data can generate numerous errors) are also arguable. In practice, the disintegration of the data and application prevents the formation of multi statements and reports as well as advanced forecasting and simulations on the structure of employment and payroll. It should be noted that an integral element of the so-called "high-end" modern information systems is called report generator. This tool allows modification of the existing and construction of new combinations, reports and statistics, and graphical visualisation of statistical data using various types of graphs. Access to individual reports should be strictly related to the implemented mechanisms for authentication, roles and permissions.

\subsection{Implementation of the functionality in the area of payroll including the integra- tion of financial-accountant module}

The first stage of works (construction of the Municipal Transport Company standardised staff system) will centralise payroll (second stage) and automatic (errorfree) data transfer to the financial-accounting system and the "Payer." Calculating payroll (Fig. 2) is a relatively simple process that comprises a sequence of successive operations:

- definition of payroll includes the following: payroll ID number, the taxable and accounting period,

- download data from the source (employees and payroll components): based on a payroll template, previous payroll or manually entered data,

- payroll configuration: download of parameters in force at the payroll date (based on the fixed documents and closed flow documents),

- conversion of downloaded components and checking of calculations,

- automated export and payroll accounting (financial accounting module): on the basis of pre-prepared accounting principles. 


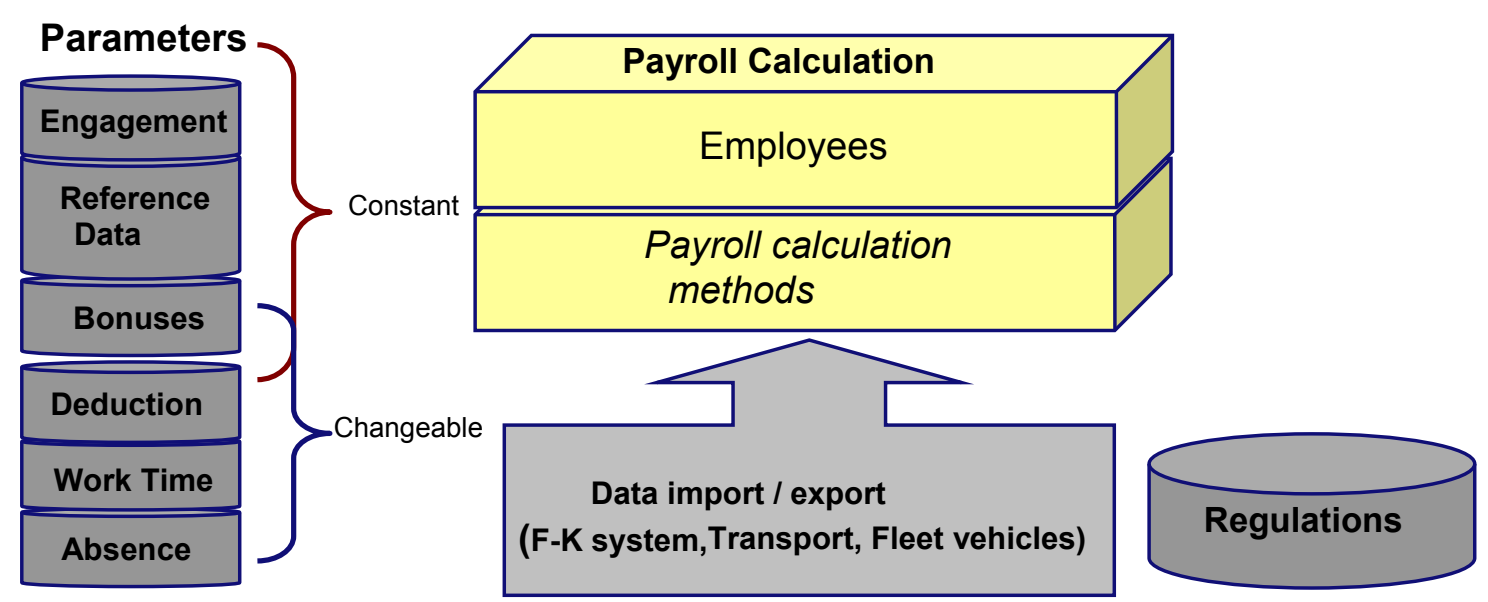

Figure 2. Module functional architecture supporting calculating payroll (source: own elaboration)

The Municipal Transport Company enterprise payroll system should guarantee the settlement of wages for different occupational groups. In short, the first group settlements are the workers employed in the position of white collar workers, then the drivers and blue-collar workers (staff, facilities and contract workers). The introduction of a central payroll system will eliminate the disintegration of existing applications that enables fully automatic (error-free) data transfer to the financial accounting system and the "Payer" program. Introduction of the enterprise system will provide real savings that result from the centralisation of organisational structures in the process of payroll (operational level), and also enable the rational implementation of remuneration policies (strategic level).

\subsection{Implementation of the functionality in the area of strategic staff management}

The launching of financial accounting system (i.e. the end of stage I and stage II) is the basis for the development and implementation of the so-called Municipal Transport Company (MPO) personnel policy, as well as adequate solutions to support the strategic management of HR. In the implementation of the so-called "soft elements of HR", the flexibility of the implemented system is extremely important, i.e. the possibility of customisation and adaptation to the specific needs of the enterprise as well as the qualifications and experience of the company that accomplishes the implementation project.

- Flexibility and customisation of the software

IT solution should support the development of personnel policies in accordance with the mission and strate- gy of the company. More specifically, in the process of implementation the appropriate software components are flexibly selected, combined and configured. For example, in modules such as managerial portal and strategic scorecard, great emphasis is also put on the appropriate configuration of visual elements. In the process of implementation configured elements affect: ergonomics and the information content of the dialog boxes (or websites), categorisation and filtering of data (a set of panels, drop-down lists and selection screens) as well as the visualisation of data using summaries, diagrams and charts.

- Knowledge and experience of the team of consultants on the side of the company that is implementing the implementation project

Traditionally, based on many years of experience, a team of consultants has many scenarios, models and preconfigured solutions that greatly accelerate the process of developing organisational computer solutions for the next customer.

At the operational level, the most important benefits of the introduction of new organisational and information solutions may include: computer aided recruitment process, the implementation of the electronic training system and employee portal. On the other hand, at the strategic level, the implementation of tools supporting the analysis of staff needs as well as verification and evaluation of personnel is particularly important.

- Operational level

- Computer aided recruitment process. On the basis of the automated comparison of information on the required recruitment qualifications 
and candidate skills database, it is possible to obtain a ranking list of candidates. Organisational and economic benefits: a high degree of accuracy with candidate selection for a specific position, reduction of operating costs.

- Direct employee access to personal information via terminals and Intranet (within its powers) and the submission of some documents (such as leave requests) in electronic form. Organisational and economic benefits: accelerating quality improvement in information access, and reduction of personnel costs related to employee service in the branches.

- Planning and organising effective personnel training (applying e-learning software). Organisational and economic benefits: improvement in teaching effectiveness and cost reduction (research conducted by Garthner Group shows that electronic training are about $40 \%$ cheaper than traditional forms).

- Strategic level

- Analysis of staffing needs. Having information about the skill set (employees) and required (position, etc.) qualifications, it is possible to analyse training and staffing needs, check the use of staffing potential, create a career path, study the effects of changes in staffing, keep internal and external recruitment, draw up ranking lists, and create job descriptions.
- Employee assessment performance. Implementation of the periodic appraisal system; comparative analysis of the so-called current review of personnel ratings with archival data.

In summary, the modern systems supporting staff management offer predefined solutions in the area of building the company organisational structure, handling the recruitment, training, competency management and development strategy of the availed HR. The last phase of the project was the implementation of functionality in the so-called area of strategic HR management.

\section{IT and integration aspects of the project}

System supporting staff management should be characterised by the so-called openness, i.e. the possibility of data exchange and integration with other Municipal Transport Company (MPO) systems, in particular, with financial accounting package and "Transport" system (Fig. 3).

In practice, there are quite often solutions found where personnel system is integrated with external (separate) financial software. Batch processing is used in data transmission, in subsequent accounting periods. Thus, in the course of the project, content and format of the so-called swap file must be determined.

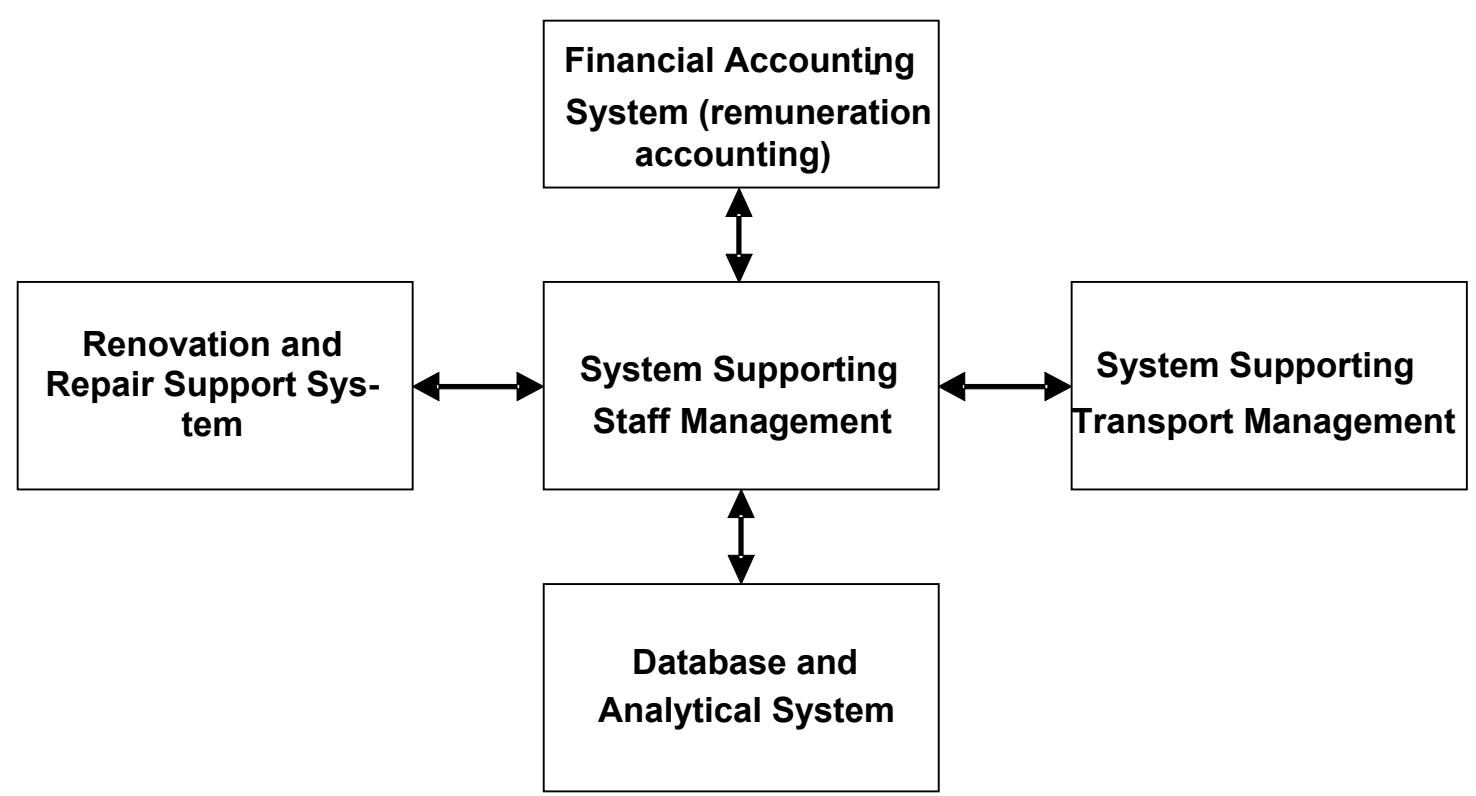

Figure 3. Integration of supporting staff management system with other information systems (source: own elaboration) 
The computerisation of the transport process includes the planning of work time drivers (including leaves, holidays and sick leaves) and the disposition that requires the development of integration solutions between the support staff management system and "Transport" system.

The planned division of tasks between system supporting the functioning of the transport process and modules of personnel-payroll package requires an elaboration of the infrastructure integration project and the methods and frequency of data exchange. The number of objects and their attributes to be exchanged between different subsystems, agreed data formats and synchronisation method should be taken into account in designing integration solutions.

\section{$4 \quad$ Summary}

European initiatives addressing the problem of the EU's competitiveness on a global scale increasingly emphasise the key role of information and communication technology in the transformation of the EU towards a knowledge-based society. In accordance with the priorities of the "Europe 2020 Strategy", an effective use of computer technology (implementation of integrated systems MRP/ERP), communication techniques (digital telephony, Internet, Intranet) and knowledge management tools, among others, Business Intelligence, OLAP and Data Mining (cf. [1, 3, 9]) will play an important role in the development of Polish companies.

Comprehensive computerisation is, therefore, an integral part of strategy to strengthen the competitive potential of the company, as well as the implementation of the restructuring changes. The purpose of this process is continuous reduction of operating costs and provision of support to the new innovative forms of economic activity.

A rational management of personnel resources was implemented in the analysed communication company. A system of central staff registration and a package of tools to support the analysis and monitoring of personnel resources were also introduced. A standardised remuneration accounting system was implemented and process for handling payroll obligations was modernised. Completion of particular work and implementation tasks were associated with the restructuring personnel process. An integral part of the process of HR and payroll centralisation had an effect on the new organisation of work, development of a new document flow and tasks and responsibilities distribution. However, the organisational changes of the realisation of specific implementation tasks should be introduced gradually that justify the division into three project phases.

Domestic passenger transport market is mature and competitive. Local authorities and local government institutions are responsible for the smooth functioning of municipal transport and operators of particular communication routes and lines. The selection process of company passenger services takes place in a non-limited tender according to the Public Procurement Law rules and regulations. Customarily, the primary criterion in tender proceedings is the unit price for the so-called vehicle kilometre. On this basis, the offer price of operating on individual routes and lines is calculated.

The elements of cost in the investigated company include over $58 \%$ of direct labour costs incurred in the form of remuneration paid to the drivers, staff facilities and white collar workers (the remaining costs are identified with $18 \%$ of fuel, $16 \%$ of service and maintenance of fleet vehicles, $8 \%$ of outsourcing and fiscal charges). Centralisation and integration procedures in the personnel area allowed the current staff needs analysis, verification and selection of staff and effective wage fund management. The economic effect of the process of comprehensive computerisation of the personnel process are the following: reduction of operating costs associated with personnel-payroll service, savings resulting from the introduction of a standardised wage policy, and more importantly the possibility of forecasting and simulation of salary costs based on analysis of historical data and analysis of employee future liabilities arising from wage policy and wage indexation.

As already mentioned, the implementation of information system supporting the personnel process was to improve not only the staff-payroll processes but above all management processes concerning strategic planning of the employment and wage policies shaping the future. Employees' remuneration is a key component of the company operating costs and, thus, the analysis of current and projected payment rates is undoubtedly the basis for a reliable calculation of the offer price for the provision of services in future tendering. The synergistic effect takes place here. Restructuring and computerisation of the personnel pro- 
cess have a direct impact on the Municipal Transport Company (MTP) strategy to gain a competitive advantage in the passenger transport market where the price service is the basis for the contract calculated as the price per vehicle kilometre.

The tangible result of the implementation of the integrated system is, therefore, not only streamlining and computerisation of primary and secondary processes, but mainly to support decision-making and management processes. Unfortunately, several times the scope of the project implementation is limited to run functions in support of the operational area that in practice is seen as a simple replacement of the software. Research carried out in the MTP showed that the launch of the functionality to support management processes, i.e. controlling of wages in conjunction with the rational planning of employment, results in longterm savings while increasing the competitiveness of the company.

\section{$5 \quad$ References}

[1] Badanie wptywu informatyzacji na dziatanie urzędów administracji publicznej w Polsce w 2011 ro$k u$ (2011). Report of a quantitative study commissioned by MSWIA.

[2] Buckley P., Minette K., Joy D., Michaels J. (2004) - The use of an automated employment recruiting and screening system for temporary professional employees.A case study. Human Resource Management, Issue 2-3, pp. 233-241.

[3] Europejska Agenda Cyfrowa w pracach i planach polskich instytucji rządowych (2011). Ministerstwo Spraw Wewnętrznych. Departament Administracji i Społeczeństwa Informacyjnego.
[4] Ferran C., Salim R. (2008) - Enterprise Resource Planning for Global Economies: Managerial Issues and Challenges, Information Science Reference.

[5] Grzebyk M., (2009) - Koncepcja klastra a wspótdziałanie i konkurencyjność przedsiębiorstw [in] Przedsiębiorstwo i region, No. 1, Konkurencyjność a innowacyjność, Rzeszów.

[6] Kostera M. (1997) - Zarzadzanie personelem. Polskie Wydawnictwo Ekonomiczne, Warszawa, pp. 23-24.

[7] Listwan T. (2004.) - Zarzadzanie kadrami. Warszawa, C.H. Beck, Ch. 14, pp. 266-285.

[8] Ptak C. (2004) - ERP Tools, Techniques, and Applications for Integrating the Supply Chain. CRC Press LLC, second edition.

[9] Spoleczeństwo informacyjne w liczbach (2012). Ministerstwo Administracji i Cyfryzacji. Departament Społeczeństwa Informacyjnego.

[10] Wallace T., Kremzar M. (2001) - ERP: Making It Happen The Implementers' Guide to Success with Enterprise Resource Planning. John Wiley \& Sons.

[11] Zając P. (2010) - Trendy rozwojowe i zmiany gospodarcze $w$ regionie. Projekt realizowany na podstawie umowy Nr UDA-POKL.08.01.02-14-35/1000 o dofinansowanie Projektu Trendy rozwojowe i zmiany gospodarcze $\mathrm{w}$ regionie $\mathrm{w}$ ramach Programu Operacyjnego Kapitał Ludzki.

[12] Zaskórski P. (2005) - Strategie informacyjne warzadzaniu organizacjami gospodarczymi. WAT, Warszawa. 